\title{
Further evaluation of herbicides in peppers'
}

\author{
Li C. Liu, ${ }^{2}$ Ismael Reyes-Soto, ${ }^{,}$Elvin Caraballot and Nilsa Acin ${ }^{5}$
}

\begin{abstract}
Three field experiments were conducted from 1989 to 1990 with transplanted peppers at the Fortuna Substation. In the first and second experiments, six herbicides were evaluated for weed control in cv. Key largo and ev. Blanco del Pais, respectively. In the first experiment, clomazone at 1.68 and $3.36 \mathrm{~kg}$ ai/ha and fluazifop-P at 0.42 and $0.84 \mathrm{~kg}$ ai/ha controlled grasses effectively. The highest pepper yield was obtained from the weeded check plots, followed by those of clomazone at $3.36 \mathrm{~kg}$ ai/ha and fluaxifop-P plus one supplementary handweeding treatment. In the second experiment, fluazifop-p at $0.84 \mathrm{~kg}$ ai/ho plus one handweeding, and fluazifop-P at $0.42 \mathrm{~kg}$ ai/ha + bentazon at 2.34 tha mixture gave good weed control. With this treatment, peppers outyielded all other herbicide treatments. In the third experiment with cv. Cubanelle, clomazone at either 1.12 or $2.24 \mathrm{~kg}$ ai/ha in sequential application with paraquat at $0.56 \mathrm{~kg}$ ai/ha gave excellent control of weeds. Metolachor at 2.24 and 4.46 $\mathrm{kg}$ ai/ha in sequential application with paraquat at $0.56 \mathrm{~kg}$ ai/ha provided good to excellent control of weeds. The highest pepper yield was obtained with clomazone at $2.24 \mathrm{~kg}$ ai/ha in sequential application with paraquat at $0.56 \mathrm{~kg}$ ailha. This yield was followed closely by that with clamarone at a lower rate in sequential application with paraquat at $0.56 \mathrm{~kg}$ ai/ha. Other herbicide treatments, with the exception of oxyfluorfen alone and fluazifop alone also resulted in good pepper yields.
\end{abstract}

\section{RESUMEN}

Evaluación de otros herbicidas para pimiento

En la Subestación de Fortuna se realizaron tres experimentos de herbicidas con pimiento desde 1989 hasta 1990 . En el primero y segundo experimentos se evaluaron seis herbicidas en los cultivares Key Largo y Blanco del País, respectivamente. Se logro un control excelente de las gramineas con clomazone a 1.68 y $3.36 \mathrm{~kg}$. p.a./ha. $y$ con fluazifop-P at 0.42 y $0.84 \mathrm{~kg}$. p.a./ha. El rendimiento más alto se obłuvo con el tratamiento testigo, desyerbo a mano, seguido por el de clomazone a $\mathbf{3 . 3 6}$ kg. p.a./ha. y fluazifop-P a 0.84 kg. p.a./ha. + desyerbo suplementario, los cuales controlaron bien las malezas y estuvieron relacionados con un mayor rendimiento. En al fercer experimento, utilizando la cultivar Cubanelle, se encontró que el clomazone a 1.12 • a $2.24 \mathrm{~kg}$. p.a./ha. aplicado en secuencia con el paraquat a $0.56 \mathrm{~kg}$. p.a./ha. controlo excelentemente las malezas. El tratamiento de metolaclor a $2.2404 .46 \mathrm{~kg}$. p.a./ ha. aplicado en secuencia con el paraquat a $0.56 \mathrm{~kg}$. p.a./ha. tambión control6 bien las malezas. El rendimiento mas alto so obtuvo con

'Manuscript submitted to Editorial Board 7 May 1991.

${ }_{2}^{2}$ Plant Physiologist, Department of Crop Protection.

${ }^{3}$ Associate Horticulturist, Department of Horticulture.

-Research Assistant, Department of Horticulture.

${ }^{5}$ Associate Chemist, Department of Crop Protection. 
clomazone a $2.24 \mathrm{~kg}$. p.a./ha. aplicado en secuencia con paraquat a 0.56 kg. p.a./ha. seguido por el mismo herbicida a dosis mós baja aplicado en secuencia con el paraquat a $0.56 \mathrm{~kg}$. p.a./ha. Con los demás herbicidas, excepto con oxifluorfen y fluazifop solos, también se lograron buenos rendimientos.

\section{INTRODUCTION}

Pepper (Capsicum annuum L.) is second only to tomato and pumpkin among vegetable crops of economic importance in Puerto Rico. In 198889 , local production was 4,218 metric tons, with a farm value of $\$ 2.9$ million (1). Importation, chiefly from the Dominican Republic, has reached nearly $50 \%$ of the total consumption in recent years.

Weeds interfere with pepper production by competing with the crop for light, water and nutrients. The critical period of weed competition under local conditions extends from the time of transplanting to the first five weeks (3). During this period, weeds have to be controlled to avoid yield losses.

Considerable weed control research has been conducted in recent years in an attempt to improve herbicide efficiency $(4,6,7,9,10,11)$. The use of plastic and other mulches (rice straws, coffee leaves and residues, and sugarcane trash) for weed control was tested in pepper production (3). An integrated weed control system involving the use of plastic mulch and post directed spray of paraquat was also studied (5). Although the use of plastic mulching is common today, the use of herbicides is an important component in an integrated weed management program (8).

The present study was thus initiated to evaluate clomazone $\{2[$ (2chlorophenyl) methyl]-4,4 dimethyl-3-isozolidinone\}, fluazifop-P $\{( \pm)-2-$ [4-(5-\{trifluoromethyl\}-2-pyridinyl)oxy]phenoxy] propanoic acid\}, and metolachor [2-cloro-N-(2-ethyl-6-methylphenyl)-N-(2-metnoxy) acetamide]. The effectiveness of certain sequential herbicide combinations was also evaluated in the same study.

\section{MATERIALS AND METHODS}

First and Second Experiments

Both field experiments were established on a Mollisol soil (organic matter 1.5, $\mathrm{pH}$ 7.3) at the Fortuna Substation 22 February 1989. The experimental designs were a randomized complete block with four replications. Pepper cultivars Key Largo and Blanco del País were used for the first and second experiments, respectively. The plot consisted of three double rows of pepper plants spaced at $1.8 \mathrm{~m}$. The planting distance was $30 \mathrm{~cm}$ between plants in a zigzag fashion. The pre-plant application of clomazone (COMMAND), ${ }^{6}$ napropamide (DEVRINOL) and oxv-

${ }^{6}$ Trade names in this publication are used only to provide specific information. Mention of a trade name does not constitute a warranty of equipment or materials by the Agricultural Experiment Station of the University of Puerto Rico, nor is this mention a statement of preference over other equipment or materials. 
fluorfen (GOAL) was made 21 February 1989. We used a portable $\mathrm{CO}_{2}$ sprayer connected to a 4-nozzle boom to deliver a spray volume of 311 $\mathrm{L} / \mathrm{ha}$ at $292 \mathrm{kPa}$ pressure. Six-week-old seedlings of both cultivars were transferred to the field one day after herbicide application. The first postemergence application of bentazon (BASAGRAN), fluazifop-P (FUSILADE) and lactofen (COBRA) was made 13 March 1989 with a knapsack sprayer to deliver a spray volume of $468 \mathrm{~L} / \mathrm{ha}$. The second postemergence application of fluazifop-P was made 25 April 1989. Weeded and unweeded checks were included in both experiments. A drip irrigation system was used in all of these experiments. For insect and disease control, Javelin + Kocide at the recommended rates was applied twice, 3 and 10 March 1989. Other pesticide applications and horticultural practices followed the standard recommendation of the Agricultural Experiment Station (2). The check plots were handweeded three times from late march to late June 1989. Weed control and phytotoxicity data were recorded periodically. Peppers were picked four times from May to July 1989 .

\section{Third Experiment}

The experiment was established 7 January 1990 on the same Mollisol soil at the Fortuna Substation. The preplant herbicides clomazone, napropamide, oxyfluorfen and metolachor (DUAL) were applied with the same co-sprayer connected to a 4-nozzle boom to deliver $180 \mathrm{~L} / \mathrm{ha}$ spray volume 10 January 1990. Six-week-old cultivar Cubanelle was transferred to the field the day after herbicide application. Postemergence applications of fluazifop, bentazon, ammonium sulfate and paraquat were made 8 and 27 February 1990. The last application of paraquat was made at the end of March 1990. Weeded and unweeded checks were included in the experiment. Weeds were removed from check plots 1 March and 1 May 1990. Weed control and phytotoxicity were recorded periodically. Fungicides Captan, Kocide 101, Manzate and Dithane M-22 at their recommended rates were used for disease control. Diazinon AG-500, Lannate and Guthion at the recommended rates were used for insect control. Other cultural practices were similar to those of the first experiment. Peppers were picked three times from May to July 1990.

\section{RESULTS AND DISCUSSION}

First and Second Experiments

The predominant weed species present in the experimental area were jungle rice (Echinocloa colonum L.), crabgrass (Digitaria sanguinalis L.), Johnson grass (Sorghum halepense L.), pigweed (Amaranthus dubius Mart. ex. Thell.) wild poinsettia (Euphorbia heterophylla L.), Jimsonweed (Datura stramonium L.), spiderflower (Cleome gynandra L.), yellow spiderflower (Cleome viscosa L.), horse purslane 
TABLE 1.-Effect of herbicide treatments on weed contral, phytotoxicity, and yield of pepper cultivar Key Largo.

\begin{tabular}{|c|c|c|c|c|c|c|c|}
\hline \multirow[b]{2}{*}{ Treatment } & \multicolumn{4}{|c|}{ Weed control' } & \multicolumn{2}{|c|}{ Phytotoxicity² } & \multirow[b]{2}{*}{ Yield $^{*}$} \\
\hline & $\begin{array}{c}\text { Broadleaf } \\
3-15-89\end{array}$ & $\begin{array}{l}\text { Grasses } \\
3-15-89\end{array}$ & $\begin{array}{c}\text { Broadleaf } \\
3-29-89\end{array}$ & $\begin{array}{l}\text { Grasses } \\
3-29-89\end{array}$ & $3-15-89$ & $3-29-89$ & \\
\hline & $\ddot{0}$ & $\%$ & \% & $\%$ & & & $\underline{\mathrm{kg} / \mathrm{ha}}$ \\
\hline 1. Clomazone $1.68 \mathrm{~kg}$ ai $/ \mathrm{ha}$ & 33 & 95 & 20 & 93 & 0.5 & 0 & $9,600 \mathrm{abc}$ \\
\hline 2. $\quad " \quad "$ & 50 & 98 & 30 & 95 & 1.5 & 1.0 & $10,776 a b$ \\
\hline 3. Napropamide $2.24 \mathrm{~kg}$ ai/ha & 38 & 60 & 15 & 33 & 0 & 0 & $2,967 \mathrm{e}$ \\
\hline $\begin{array}{l}\text { 4. Napropamide } 2.24 \mathrm{~kg} \text { ai/ha } \\
+ \text { Bentazon } 2.34 \mathrm{l} / \mathrm{ha}\end{array}$ & 45 & 68 & 60 & 40 & 0 & 1.3 & 4,334 cde \\
\hline $\begin{array}{l}\text { 5. Napropamide } 2.24 \mathrm{~kg} \text { ai/ha } \\
+ \text { Bentazon } 4.68 \mathrm{l} / \mathrm{ha}\end{array}$ & 38 & 70 & 73 & 38 & 0 & 1.5 & $2,172 \mathrm{e}$ \\
\hline $\begin{array}{l}\text { 6. Napropamide } 2.24 \mathrm{~kg} \text { ai/ha } \\
+ \text { Lactofen } 0.94 \mathrm{ha}\end{array}$ & 35 & 75 & 95 & 38 & 0 & 4.0 & $1,558 \mathrm{e}$ \\
\hline $\begin{array}{l}\text { 7. Napropamide } 2.24 \mathrm{~kg} \text { ai/ha } \\
+ \text { Lactofen } 1.88 \mathrm{lha}\end{array}$ & 43 & 65 & 98 & 35 & 0 & 4.5 & $2,140 \mathrm{e}$ \\
\hline $\begin{array}{l}\text { 8. Fluazifop } 0.42 \mathrm{~kg} \text { ai } / \mathrm{ha} \\
+ \text { Bentazon } 2.34 \mathrm{l} / \mathrm{ha}\end{array}$ & - & - & 70 & 100 & 0 & 1.3 & $6,061 b c$ \\
\hline 9. Oxyfluorfen $0.29 \mathrm{~kg}$ ai/ha & 53 & 73 & 25 & 40 & 0 & 0 & $3,592 \mathrm{de}$ \\
\hline 10. Weeded check & - & - & 100 & 95 & 0 & 0 & $11,412 \mathrm{a}$ \\
\hline 11. Non-weeded check & 0 & 0 & 0 & 0 & 0 & 0 & $1,303 e$ \\
\hline $\begin{array}{l}\text { 12. Fluazifop } 0.42 \mathrm{~kg} \text { ai/ha } \\
+ \text { one handweeding }\end{array}$ & - & - & 0 & 100 & - & 0 & 8,784 abcd \\
\hline $\begin{array}{l}\text { 13. Fluazifop } 0.84 \mathrm{~kg} \mathrm{ai} / \mathrm{ha} \\
+ \text { one handweeding }\end{array}$ & - & - & 0 & 100 & - & 0 & 5,958 bcde \\
\hline
\end{tabular}

'Weed control ratings are based on a 0 to 100 scale; $0=$ no control, $100=$ perfect control.

${ }^{2}$ Phytotoxicity evaluations are based on a 0 to 5 scale; $0=$ no injury, $5=$ completely killed.

${ }^{3}$ Means bearing the same letter or letters do not differ significantly at 0.05 probability level. 
(Trianthema portulacastrum L.), and purple nutsedge (Cyperus rotun. dus L.). Clomazone at both rates gave excellent control of the abovementioned grasses in both experiments (tables 1 and 2). The broadleaf weeds such as pigweed and spiderflower were not effectively controlled by clomazone. Napropamide alone gave fair grass control, but was deficient on broadleaf weeds. Napropamide in sequential application with lactofen gave excellent control of broadleaf weeds, but was weak on grasses. Fluazifop at both rates gave excellent control of grasses, but it was ineffective against all broadleaf weeds. One supplementary weeding was needed to remove all broad leaf weeds in fluazifop treatment at the end of March 1990. Fluazifop at $0.42 \mathrm{~kg}$ ai/ha in sequential application with bentazon at $2.34 \mathrm{~L} / \mathrm{ha}$ controlled both types of weeds. Clomazone at both rates caused only a slight initial crop injury that was later outgrown with no apparent detrimental effect. The postemergence application of lactofen caused severe crop injury and resulted in the death of a large number of pepper plants. None of the fluazifop-P treatments caused any apparent crop injury in these two experiments.

The highest pepper yield of Key Largo cultivar was obtained in the weeded check (table 1). This treatment did not differ significantly in yield from the clomazone treatments or either rate of fluazifop + one handweeding treatment, or fluazifop + bentazon at $2.34 \mathrm{~L} / \mathrm{ha}$. Other herbicide treatments yielded significantly less than the weeded check. The highest yield of Blanco del País was also obtained with the weeded check (table 2). This treatment did not differ significantly from treatments with fluazifop-P at $0.84 \mathrm{~kg}$ ai/ha + one supplementary weeding, and fluazifop at $0.42 \mathrm{~kg}$ ai/ha + bentazon at $2.34 \mathrm{~L} / \mathrm{ha}$ rate. Other herbicide treatments had significantly lower yields than the weeded check.

Third Experiment

The predominant weed species in the experimental area were similar to those listed in the previous experiments. Clomazone at either rate in sequential application with paraquat at $0.56 \mathrm{~kg}$ ai/ha rate provided the best sustained weed control (table 3). Napropamide at $2.24 \mathrm{~kg}$ ai/ha in sequential application with paraquat at $0.56 \mathrm{~kg}$ ai $/$ ha controlled weeds better than its counterpart with fluazifop at $0.42 \mathrm{~kg}$ ai/ha. Fluazifop-P at $0.42 \mathrm{~kg}$ ai/ha, either alone or in combination, gave excellent grass control, but was ineffective against broadleaf weeds. Oxyfluorfen at both rates controlled both broadleaf weeds and grasses, but resulted in severe crop injury. Metolachor at either rate in sequential application with paraquat at $0.56 \mathrm{~kg}$ ai/ha gave good to excellent control of weeds. Slight crop injury was noted when metolachor was first applied, but pepper plants recovered rapidly. Paraquat as a post directed spray caused a slight contact injury, but plants recovered completely with no detrimental effect on yields. 
TABLE 2-Effect of herbicide treatments on weed control, phytotoxicity, and yield of pepper cultivar Blanco del Pais

\begin{tabular}{|c|c|c|c|c|c|c|c|}
\hline \multirow[b]{2}{*}{ Treatment } & \multicolumn{4}{|c|}{ Weed control' } & \multicolumn{2}{|c|}{ Phytotoxicity ${ }^{2}$} & \multirow[b]{2}{*}{ Yield $^{3}$} \\
\hline & $\begin{array}{c}\text { Broadleaf } \\
3-15-89\end{array}$ & $\begin{array}{l}\text { Grasses } \\
3-15-89\end{array}$ & $\begin{array}{l}\text { Broadieaf } \\
3-29-89\end{array}$ & $\begin{array}{l}\text { Grasses } \\
3-29-89\end{array}$ & $3-15-89$ & $3-29-89$ & \\
\hline & $\%$ & $\%$ & $\%$ & 亘 & & & kgha \\
\hline 1. Clomazone $1.68 \mathrm{~kg} \mathrm{ai} / \mathrm{ha}$ & 38 & 94 & 25 & 92 & 1.0 & 0 & $6,991 \mathrm{~cd}$ \\
\hline $2 . \quad " \quad "$ & 58 & 99 & 40 & 95 & 2.5 & 1.5 & $10,850 \mathrm{bc}$ \\
\hline 3. Napropamide $2.24 \mathrm{~kg}$ ai/ha & 30 & 65 & 20 & 35 & 0 & 0 & 2,755 de \\
\hline $\begin{array}{l}\text { 4. Napropamide } 2.24 \mathrm{~kg} \text { ai/ha } \\
+ \text { Bentazon } 2.34 \mathrm{lha}\end{array}$ & 38 & 74 & 80 & 36 & 0 & 1.5 & $4,471 \mathrm{~cd}$ \\
\hline $\begin{array}{l}\text { 5. Napropamide } 2.24 \mathrm{~kg} \text { ai/ha } \\
+ \text { Bentazon } 4.68 \mathrm{lha}\end{array}$ & 40 & 75 & 81 & 36 & 0 & 2.0 & 2,119 de \\
\hline $\begin{array}{l}\text { 6. Napropamide } 2.24 \mathrm{~kg} \text { ai/ha } \\
+ \text { Lactofen } 0.94 \mathrm{lha}\end{array}$ & 38 & 71 & 98 & 35 & 0 & 4.2 & $3,306 \mathrm{de}$ \\
\hline $\begin{array}{l}\text { 7. Napropamide } 2.24 \mathrm{~kg} \text { ai/ha } \\
+ \text { Lactofen } 1.88 \mathrm{Vha}\end{array}$ & 40 & 79 & 98 & 38 & 0 & 4.8 & $1,642 \mathrm{e}$ \\
\hline $\begin{array}{l}\text { 8. Fluazifop } 0.42 \mathrm{~kg} \text { ai/ha } \\
\text { + Bentazon } 2.34 \mathrm{lha}\end{array}$ & - & - & 84 & 98 & 0 & 1.5 & $4,569 \mathrm{ab}$ \\
\hline 9. Oxyfluorfen $0.29 \mathrm{~kg}$ ai $/ \mathrm{ha}$ & 38 & 73 & 26 & 40 & 0 & 0 & 2,977 de \\
\hline 10. Weeded check & - & - & 100 & 95 & 0 & 0 & $18,468 \mathrm{a}$ \\
\hline 11. Non-weeded check & 0 & 0 & 0 & 0 & 0 & 0 & $615 \mathrm{e}$ \\
\hline $\begin{array}{l}\text { 12. Fluazifop } 0.42 \mathrm{~kg} \text { ai/ha } \\
+ \text { one handweeding }\end{array}$ & - & - & 0 & 100 & - & 0 & $12,704 \mathrm{~b}$ \\
\hline $\begin{array}{l}\text { 13. Fluazifop } 0.84 \mathrm{~kg} \text { ai/ha } \\
+ \text { one handweeding }\end{array}$ & - & - & 0 & 100 & - & 0 & $15,025 \mathrm{ab}$ \\
\hline
\end{tabular}

'Weed control ratings are based on a 0 to 100 scale; $0=$ no control, $100=$ perfect control

${ }^{2}$ Phytotoxicity evaluations are based on a 0 to 5 scale; $0=$ no injury, $5=$ completely killed.

${ }^{3}$ Means bearing the same letter or letters do not differ significantly at 0.05 probability level. 
TABLE 3.-Effect of herbicide treatments on weed control, phytotoxicity, and yield of pepper cultivar Cubanelle.

\begin{tabular}{|c|c|c|c|c|c|c|c|}
\hline \multirow[b]{2}{*}{ Treatment } & \multicolumn{4}{|c|}{ Weed control' } & \multirow{2}{*}{\multicolumn{2}{|c|}{ Phytotoxicity }} & \multirow[b]{2}{*}{ Yield $^{2}$} \\
\hline & $\begin{array}{c}\text { Broadleaf } \\
2-8-90\end{array}$ & $\begin{array}{l}\text { Grasses } \\
2-8-90\end{array}$ & $\begin{array}{c}\text { Broadleaf } \\
3-5-90\end{array}$ & $\begin{array}{c}\text { Grasses } \\
3-5-90\end{array}$ & & & \\
\hline & $\%$ & th & $\ddot{z}$ & $\%$ & & & $\mathrm{~kg} / \mathrm{ha}$ \\
\hline $\begin{array}{l}\text { 1. Clomazone } 1.12 \mathrm{~kg} \mathrm{ai} / \mathrm{ha} \\
+ \text { paraquat } 0.56 \mathrm{~kg} \text { ai/ha }\end{array}$ & 55 & 95 & 98 & 98 & 0 & 0.8 & 7,548 a \\
\hline $\begin{array}{l}\text { 2. Clomazone } 2.24 \mathrm{~kg} \text { ai/ha } \\
+ \text { paraquat } 0.56 \mathrm{~kg} \mathrm{ai} / \mathrm{ha}\end{array}$ & 66 & 98 & 98 & 98 & 0.8 & 1:0 & 7,578 a \\
\hline $\begin{array}{l}\text { 3. Napropanide } 2.24 \mathrm{~kg} \text { ai/ha } \\
+ \text { fluazifop } 0.42 \mathrm{~kg} \text { ai/ha }\end{array}$ & 58 & 55 & 40 & 90 & 0 & 0 & 5,839 a \\
\hline $\begin{array}{l}\text { 4. Napropanide } 2.24 \mathrm{~kg} \text { ai/ha } \\
+ \text { paraquat } 0.56 \mathrm{~kg} \text { ai/ha }\end{array}$ & 60 & 56 & 95 & 98 & 0 & 0.5 & 5,401 a \\
\hline 5. Fluazifop $0.42 \mathrm{~kg} \mathrm{ai} / \mathrm{ha}$ & - & - & 0 & 90 & 0 & 0 & $1,200 \mathrm{~b}$ \\
\hline $\begin{array}{l}\text { 6. Fluazifop } 0.42 \mathrm{~kg} \text { ai/ga } \\
+(\mathrm{NH} 4)_{2} \mathrm{SO}_{4} 1.18 \mathrm{~kg} / \mathrm{plot}\end{array}$ & - & - & 0 & 70 & 0 & 1.0 & $1,048 \mathrm{~b}$ \\
\hline 7. Oxyfluorfen $0.42 \mathrm{~kg}$ ai/ha & 98 & 100 & 90 & 95 & 2.8 & 4.0 & $1,821 b$ \\
\hline 8. Oxyfluorfen $0.82 \mathrm{~kg}$ ai/ha & 100 & 100 & 98 & 98 & 3.5 & 4.5 & $977 \mathrm{~b}$ \\
\hline $\begin{array}{l}\text { 9. Metalachor } 2.24 \mathrm{~kg} \text { ai/ha } \\
+ \text { paraquat } 0.56 \mathrm{~kg} \text { ai/ha }\end{array}$ & 90 & 95 & 98 & 98 & 1.5 & 2.3 & 5,818 a \\
\hline $\begin{array}{l}\text { 10. Metalachor } 4.48 \mathrm{~kg} \text { ai/ha } \\
+ \text { paraquat } 0.56 \mathrm{~kg} \text { ai/ha }\end{array}$ & 93 & 100 & 98 & 98 & 2.5 & 2.8 & 5,015 a \\
\hline 11. Weeded check & - & - & 95 & 95 & 0 & 0 & $4,760 \mathrm{a}$ \\
\hline 12. Non-weeded check & 0 & 0 & 0 & 0 & 0 & 0 & $387 \mathrm{~b}$ \\
\hline
\end{tabular}

'Weed control ratings are based on a 0 to 100 scale; $0=$ no control, $100=$ perfect control.

2Phytotoxicity evaluations are based on a 0 to 5 scale; $0=$ no injury, $5=$ completely killed.

${ }^{3}$ Means bearing the same letter or letters do not differ significantly at 0.05 probability level. 
The highest pepper yield was obtained from clomazone at $2.24 \mathrm{~kg}$ ai/ha plots in sequential application with paraquat at $0.56 \mathrm{~kg}$ ai/ha (table 3), followed closely by the yield of clomazone at $1.12 \mathrm{~kg}$ ai/ha in sequential application with paraquat at $0.56 \mathrm{~kg}$ ai/ha. Neither of these treatments differed significantly from other herbicide treatments, with the exception of fluazifop-P alone or in combination with ammonium sulfate, oxyfluorfen alone treatments and the unweeded check.

It is expected that the use of clomazone at $1.12 \mathrm{~kg}$ ai/ha rate as a preplant treatment in peppers will soon be approved. The use of clomazone in sequential application with paraquat would greatly increase the weed control option for local pepper farmers, especially the small planters, who cannot afford the use of more expensive plastic mulching for weed control.

\section{LITERATURE CITED}

1. Anonymous, 1988. Facts and Figures on Puerto Rico's Agriculture. 1987-88. Dep. Agric. Office of Agricultural Statistics, Santurce, P.R.

2. Estación Experimental Agrícola, 1976. Conjunto tecnológico para la producción de hortalizas. Univ. P. R. Publ. 102.

3. Liu, L. C., J. Gonzalez and M. R. Goyal, 1984. Weed competition in transplanted sweet peppers. Proc. 20th Annual Meeting of Caribbean Food Crops Soc. 20: 198-99.

4. - 1984. Control de malezas en tomates y pimientos. Revista del Colegio de Agrónomos de Puerto Rico. p. 11 y 27.

5. —- M. Antoni-Padilla-Feliciano, M. R. Goyal and J. González-Ibánez, 1987. Integrated weed management in transplanted tomatoes and peppers under drip irrigation. J. Agric. Univ. P. R. 71(4): 349-58.

6. — and M. R. Goyal, 1989. Selective herbicides to control grasses in transplanted tomatoes and peppers. J. Agric. Univ. P. R. 73(3): 231-37.

7. Orengo-Santiago, E., N. Semidey and L. Almod6var-Vega, 1987. Influence of glyphosate and paraquat pre-transplant treatment on weed control and pepper yields. $J$. Agric. Univ. P. R. 71(1): 66-73.

8. Reyes-Pérez, L. A., L. C. Liu, and L. Almodóvar-Vega, 1986. Integrated weed control in transplanted peppers. Proc. 22th Annual Meeting of the Caribbean Food Crops Society. 22: 324-30.

9. Semidey, N. and L. Almodovar-Vega, 1987. Glyphosate on tomato and sweet pepper yields. J. Agric. Univ. P. R. 71(2): 209-16.

10. - E. Caraballo and Nilsa Acín, 1989. Broadleaf weed control in peppers with herbicides applied pre-transplant. J. Agric. Univ. P. R. 73(1): 67-73.

11. Weed Sei. Soc. of America. 1989. Herbicide handbook 6th Ed. Champion, Ill. 